\title{
Hubungan Tingkat Stres dengan Perilaku Merokok pada Remaja Laki- Laki di SMA Saraswati 1 Denpasar
}

\author{
Putu Rias Andreani ${ }^{1}$, Ni Kadek Muliawati ${ }^{2}$, Ni Luh Gede Puspita Yanti ${ }^{3}$ \\ ${ }^{1-3}$ Sekolah Tinggi Ilmu Kesehatan Wira Medika Bali \\ email: riasandreani1997@gmail.com
}

Submitted :02 /04/2020

Accepted: 16/04/2020

Published: 7/09/2020

\begin{abstract}
Smoking is a behavior that is very easily seen in everyday life. At this time cigarettes are not only consumed by adults, smoking is also one of the most common juvenile delinquents which is about $44,5 \%$ smoking consumed by teenagers. The cause of smoking among teenagers one of which is due to stress. This study aimed to to know the relationship of beetween the level stres with smoking behavior toward the teenagers. Method: This study used cross sectional method. The number of samples of this research was 65 people collecting by purposive sampling technique. The data collected by stress and smoking behavior questionnaire. Result : the teenagers have middle level of stress as much as 27 people $(41,5 \%)$ and 39 teenagers (60\%) confessed who smoke strong. Rank Spearman test results obtained $p=0,000$ with a significance value of $p<0.05$, so $0.000<0.05$. That means there is significant relationship between stress level with smoking behavior teenagers. Discussion : stress levels will be followed by smoking behavior, at a young age it is expected that the PKPR program at the Public Health Center will be improved so that adolescents better understand the effects of the dangers of smoking.
\end{abstract}

Keywords: smoking behavior, stress, teenagers

\begin{abstract}
Abstrak
Merokok merupakan perilaku yang sangat mudah dilihat dalam kehidupan sehari-hari. Pada saat ini rokok bukan saja dikonsumsi oleh orang dewasa, merokok juga merupakan salah satu kenakalan remaja yang paling sering ditemui, yaitu sekitar 44,5\% merupakan merokok di usia remaja. Penyebab merokok di kalangan remaja salah satunya yaitu karena stres. Penelitian ini bertujuan untuk mengetahui ada hubungan tingkat stres dengan perilaku merokok pada remaja laki-laki di SMA Saraswati 1 Denpasar. Metode : Penelitian ini menggunakan metode cross sectional. Jumlah sampel penelitian ini sebanyak 65 orang diambil dengan teknik purposive sampling. Pengumpulan data menggunakan kuesioner tingkat stres dan perilaku merokok. Hasil : Sebanyak 27 orang $(41,5 \%)$ merupakan tingkat stres sedang dan sebanyak 39 orang $(60 \%)$ merupakan perilaku merokok kuat. Hasil uji rank spearman didaptakan $\mathrm{p}($ value $)=0,000<0,05$ maka Ho ditolak dan Ha diterima yang berarti terdapat hubungan tingkat stress dengan perilaku merokok pada remaja laki-laki di SMA Saraswati 1 Denpasar. Diskusi : tingkat stres akan diikuti dengan perilaku merokok, dalam usia yang muda tersebut diharapkan program PKPR di puskesmas lebih di tingkatkan agar remaja lebih mengerti akan dampak bahaya merokok.
\end{abstract}

Kata Kunci : perilaku merokok, remaja, stres 


\section{PENDAHULUAN}

Masa remaja dimulai pada saat seorang anak telah mencapai usia matang, yaitu pada usia 13 tahun sampai 17 tahun dan berakhir pada usia 16 tahun sampai 18 tahun. Masa remaja merupakan masa transisi, dimana remaja kerap dibenturkan pada masalah awal kehidupan. Remaja juga akan mengalami siklus emosional yang meledak-ledak. Hal ini terjadi karena emosi remaja masih stabil, sering menggebu-gebu, sangat bersemangat, namun mudah putus asa. Hal ini biasanya memicu kenakalan pada remaja, dimana salah satu kenakalan remaja yang paling sering ditemui yaitu merokok ( Windira 2016). The ASEAN Tobacco Control Report tahun 2014 menyatakan bahwa, Indonesia menempati posisi pertama perokok terbanyak di ASEAN, dengan prevalensi sekitar 50,68\%.

${ }^{2}$ Berdasarkan survey yang dilakukan oleh Global Youth Tabacco Survey (GYTS) Indonesia, pada tahun 2014 yang dilakukan terhadap remaja berusia 13-15 tahun, sebanyak 35,3\% remaja laki-laki dan 3,4\% remaja perempuan merupakan perokok (WHO, 2014). Dilihat dari sebaran penduduk perokok berusia lebih atau sama dengan 10 tahun, menurut provinsi di Indonesia, provinsi tertinggi ada di Provinsi Riau yaitu sebesar 27,2\% sedangkan Provinsi Bali sebesar 23,5\%. Usia perokok yang paling tinggi terjadi pada usia remaja yaitu usia 10-18 tahun, dengan prevalensi 9,1\% pada tahun 2018 ( Indonesia,2018). Data Profil Kesehatan Provinsi Bali tahun 2017, prevalensi perokok menurut kabupaten/kota, jumlah perokok tertinggi ditemukan di Jembrana (17,60\%), diikuti Gianyar $(8,90 \%)$ dan Denpasar $(4,40 \%)$ (Denpasar, 2017).

Dampak merokok tidak hanya pada kesehatan fisik tetapi juga terhadap perkembangan individu. Hasil penelitian menunjukkan perilaku merokok dapat meningkatkan kecenderungan untuk mencoba zat adiktif lain dan narkoba (Aula, 2010). Hasil Penelitian Liem menyatakan bahwa, penumpukan nikotin dan berbagai macam zat kimia yang terkandung di dalam rokok akan berpengaruh terhadap kondisi stamina fisik dan berpengaruh pula secara tidak langsung terhadap motivasi belajar remaja (Liem, 2016). Widiansyah, (2014) berpendapat bahwa, salah satu faktor merokok di kalangan remaja disebabkan oleh faktor psikologis yaitu stres. Stres yang terjadi pada remaja biasanya disebabkan oleh beberapa faktor seperti faktor biologis, faktor keluarga, faktor sekolah, faktor teman sebaya, dan faktor lingkungan sosial. Merokok merupakan salah satu contoh dari strategi manajemen yang tidak efektif namun banyak disukai, meskipun semua orang mengetahui akibat negatif dari merokok, tetapi jumlah perokok semakin meningkat dan usia perokok semakin bertambah muda. Hal ini sesuai dengan penelitian yang dilakukan oleh Helmi dari Universitas Gajah Mada dengan 75 sampel, penelitian didapatkan hasil, kondisi merokok tertinggi pada saat seseorang mengalami stres sebesar $40,86 \%$ (Helmi,2000).

Upaya untuk menanggulangi dan mencegah munculnya perilaku merokok di kalangan siswa, maka perlu upaya pembinaan terhadap siswa secara terintegrasi antara sekolah dengan orang tua siswa dan masyarakat. Berdasarkan hasil studi pendahuluan yang dilakukan di SMA Saraswati 1 Denpasar, pada bulan Juli tahun 2019, didapatkan data dari guru BK (bimbingan konseling) yaitu jumlah siswa laki-laki terbanyak yang sering melakukan pelanggaran merokok yaitu pada kelas XII, dengan jumlah siswa laki-laki sebanyak 191 siswa. Hasil wawancara dengan 10 orang siswa, delapan siswa diantaranya merupakan perokok aktif dengan alasan untuk mengisi waktu luang, dan untuk menghilangkan stres serta beban pikiran karena berbagai aspek seperti tugas sekolah yang menumpuk.

\section{METODE PENELITIAN}

Penelitian ini menggunakan jenis penelitian analitik korelasi yang bertujuan 
untuk melihat ada atau tidaknya hubungan dan sejauh mana hubungan antara dua variabel dalam penelitian. Pendekatan yang digunakan yaitu cross sectional, dimana penelitian yang menekankan waktu pengukuran data variabel independent dan dependent hanya satu kali pada saat penelitian. Populasi dalam penelitian ini adalah seluruh siswa laki-laki kelas XII di SMA Saraswati 1 Denpasar. Sampel dalam penelitian ini berjumlah 65 orang dengan menggunakan tehnik non probability sampling jenis purposive sampling. Penelitian ini dilakukan di SMA Saraswati 1 Denpasar instrument penelitian berupa kuesioner tingkat stres dengan perilaku merokok. Teknik analisa data yang digunakan untuk menguji hubungan dalam penelitian ini adalah uji Rank Spearman (tingkat kepercayaan 95\% $\mathrm{p} \leq 0.05$ ).

\section{HASIL DAN PEMBAHASAN}

Tabel 1. Distribusi Frekuensi Responden Berdasarkan Tingkat Stres Remaja Laki-laki Kelas XII di SMA Saraswati 1 Denpasar Tahun 2019

\begin{tabular}{lll}
\hline $\begin{array}{l}\text { Tingkat } \\
\text { stres }\end{array}$ & $\begin{array}{l}\text { Frekuensi } \\
(\mathbf{f})\end{array}$ & $\begin{array}{l}\text { Persentase } \\
(\mathbf{\%})\end{array}$ \\
\hline Normal & 21 & 32,3 \\
Stres ringan & 8 & 12,3 \\
Stres sedang & 27 & 41,5 \\
Stres berat & 9 & 13,8 \\
\hline Total & 65 & 100 \\
\hline
\end{tabular}

Berdasarkan tabel 1 dapat diketahui dari 65 siswa, di dapatkan skor yang paling kecil yaitu pada stres ringan sebanyak delapan responden $(12,3 \%)$ dan skor paling besar yaitu pada stres sedang sebanyak 27 responden $(41,5 \%)$.

Tabel 2. Distribusi Frekuensi Responden Berdasarkan Perilaku Merokok Remaja Laki-laki Kelas XII di SMA Saraswati 1 Denpasar Tahun 2019

\begin{tabular}{lll}
\hline $\begin{array}{l}\text { Prilaku } \\
\text { Merokok }\end{array}$ & Frekuensi (f) & $\begin{array}{l}\text { Persentase } \\
(\boldsymbol{\%})\end{array}$ \\
\hline Ringan & 12 & 18,5 \\
Sedang & 11 & 16,9 \\
Kuat & 39 & 60,0 \\
Sangat Kuat & 3 & 4,6 \\
\hline Total & 65 & 100
\end{tabular}

Berdasarkan tabel 2 dapat diketahui dari 65 siswa, skor yang paling besar yaitu pada perilaku merokok kuat sebanyak 39 responden $(60,0 \%)$, dan skor yang paling kecil yaitu pada perilaku merokok sangat kuat sebanyak tiga responden $(4,6 \%)$.

Tabel 3. Distribusi Frekuensi Responden Berdasarkan Skor Tingkat Stres dengan Perilaku Merokok di SMA Saraswati 1 Denpasar Tahun 2019

\begin{tabular}{|c|c|c|c|c|c|c|c|c|c|c|c|}
\hline \multirow{3}{*}{$\begin{array}{l}\text { Tingkat } \\
\text { Stres }\end{array}$} & \multicolumn{9}{|c|}{ Prilaku Yerokok } & \multirow{3}{*}{ r } & \multirow{3}{*}{ sig, } \\
\hline & \multicolumn{2}{|c|}{ Ringan } & \multicolumn{2}{|c|}{ Sedang } & \multicolumn{2}{|c|}{ Kuat } & \multicolumn{2}{|c|}{$\begin{array}{c}\text { Sangat } \\
\text { Kuat }\end{array}$} & \multirow[t]{2}{*}{ Total } & & \\
\hline & $\mathrm{f}$ & $\%$ & $\mathrm{f}$ & $\%$ & $\mathrm{f}$ & $\%$ & $\mathrm{f}$ & $\%$ & & & \\
\hline Normal & 11 & 16,9 & 5 & 7,7 & 4 & 6,2 & 1 & 1,5 & 32,3 & \multirow{4}{*}{0,532} & \multirow{4}{*}{0,000} \\
\hline Stres Ringan & 0 & 0 & 2 & 3,1 & 6 & 9,2 & 0 & 0 & 12,3 & & \\
\hline Stres Sedang & 1 & 1,5 & 3 & 4,6 & 21 & 32,3 & 2 & 3,1 & 41,5 & & \\
\hline Stres Berat & 0 & 0 & 1 & 1,5 & 8 & 12,3 & 0 & 0 & 13,8 & & \\
\hline
\end{tabular}

Berdasarkan tabel 3 dapat diketahui dari 65 responden, yang merupakan perilaku merokok kuat dengan stress sedang sebanyak 21 responden (32,3\%) sedangkan hasil perilaku merokok sangat kuat dengan stres normal sebanyak satu responden $(1,5 \%)$. Hasil uji statistik hubungan tingkat stres dengan perilaku merokok pada remaja laki-laki yang diolah menggunakan analisis bivariat yaitu menggunakan uji rankspearman dengan diperoleh nilai $\mathrm{p}=0,000$ yang berarti $\mathrm{p}$ (value) <0,05, maka $\mathrm{H} 0$ ditolak dan Ha diterima, jadi dapat disimpulkan bahwa ada hubungan antara tingkat stres dengan perilaku merokok pada remaja laki-laki. Kekuatan hubungan dapat dilihat pada nilai koefisien korelasi (r) yaitu sebesar 0,532 yang berarti hubungan sedang antara variabel, serta arah hubungan yang positif sehingga semakin tinggi 
tingkat stres pada remaja, maka perilaku merokok pada remaja akan semakin kuat.

Berdasarkan hasil penelitian di SMA Saraswati 1 Denpasar diperoleh data secara umum, tingkat stres tertingi pada remaja berada pada tingkat stres sedang dengan jumlah 27 responden (41,5\%). Eric Ericson menyatakan bahwa, remaja merupakan usia yang paling rentan terhadap stres, hal ini disebabkan oleh adanya krisis aspek psikososial yang dialami pada masa perkembangannya, yaitu masa mencari identitas diri seperti usaha untuk menjelaskan siapa dirinya dan apa perannya dalam masyarakat ( Ericson, 2003). Remaja banyak mengalami stres disebabkan oleh kehidupan sosial dan lingkungan sekitarnya (Nasution, 2007).

Berdasarkan hasil penelitian perilaku merokok menunjukkan dari 65 responden, sebanyak 39 responden yang memiliki sikap perilaku merokok tertinggi pada tingkat perilaku merokok kuat. Tekanan psikologis merupakan faktor terbesar dalam perilaku merokok pada remaja. ${ }^{11}$ Penelitian ini sejalan dengan penelitian yang dilakukan oleh Rani di Yogyakarta yang menyatakan bahwa perilaku merokok kuat pada seorang remaja disebabkan oleh stres yang terkait dengan lingkungan sekitarnya,status emosional, tuntutan sekolah dan permasalahan dengan teman sebaya maupun orang tua (Rani, 2018). Berbeda dengan penelitian yang dilakukan oleh Saputra dengan judul hubungan antara harga diri dengan perilaku merokok pada siswa SMP laki-laki di Bukit tinggi, yang menggunakan 50 responden, dan hanya terdapat 7 responden $(14 \%)$ yang merupakan perilaku merokok kuat (Saputra,2012). Perbedaan hasil penelitian ini kemungkinan disebabkan karena penelitian yang dilakukan oleh Saputra hanya menggunakan 50 responden siswa SMP sedangkan penelitian ini menggunakan 65 responden siswa SMA. Rendahnya hasil perilaku merokok kuat pada remaja disebabkan oleh sebagian remaja memiliki self-attitude positive, mereka merasa bahwa memiliki pemahaman yang baik tentang dirinya, dan mampu menempatkan diri serta emosi dari permasalahan yang mereka alami (Saputra,2014).

Berdasarkan hasil penelitian ini terdapat hubungan tingkat stres dengan perilaku merokok pada remaja laki-laki kelas XII di SMA Saraswati 1 Denpasar, dengan hasil $\mathrm{p}($ value $)=0,000<0,05$ maka Ho ditolak dan Ha diterima, hasil koefisien korelasi menunjukkan $r_{\text {-hitung }}=0,532$ dengan korelasi dalam tingkat hubungan yang sedang, arah korelasi positif yaitu semakin tinggi tingkat stres pada remaja, maka perilaku merokok pada remaja akan semakin kuat. Hal ini sejalan dengan teori yang dikemukakan oleh Leventhal \& Cleary meningkatnya frekuensi dan intensitas perilaku merokok pada remaja disebabkan oleh adanya reaksi yang ditimbulkan dari zat yang terkandung di dalam rokok. Pengaruh dari rokok yang diperkirakan dapat menimbulkan ketenangan, menjadi salah satu penyebab yang mendorong remaja yang sedang stres melakukan tindakan merokok (Leventhal 1980). Sejalan dengan penelitian yang dilakukan oleh Pamukht (2016), yang menyatakan bahwa ada hubungan antara tingkat stres dengan perilaku merokok pada remaja laki-laki. Adanya hubungan antara tingkat stres dengan perilaku merokok disebabkan karena banyaknya remaja menghadapi berbagai tuntutan, dan godaangodaan yang lebih kompleks. Hal ini sangat berpotensi menyebabkan remaja merasa tertekan dan stres. Sebatang rokok yang dihisap dapat memberikan efek yang besar terhadap masalah yang dirasakan. Rokok dapat melupakan masalah yang dialami oleh remaja apalagi ketika sedang berkumpul dengan lingkungan yang negatif, karena pikiran hanya berfokus pada kenikmatan rokok sehingga mereka lupa akan adanya masalah, apalagi jika stres semakin tinggi maka perilaku merokok juga akan terus meningkat (Pamukh, 2016). 
Berdasarkan hasil penelitian ini, peneliti berasumsi bahwa hubungan antara tingkat stres dengan perilaku merokok di usia remaja kemungkinan disebabkan karena pada masa inilah remaja mengalami akil balik. Hal ini menyebabkan remaja cenderung mencoba perilaku yang belum pernah dilakukannya baik itu positif maupun negatif yang membuat rasa ingin taunya tinggi. Remaja lebih memilih merokok untuk mengurangi perasaan marah atau gelisah yang disebabkan oleh lingkungan sekitarnya yang bisa memicu stress. Hal ini sangat mengkhawatirkan karena merokok pada usia remaja banyak mendatangkan dampak negatif seperti merusak kesehatan, hingga menurunkan niat belajar.

\section{SIMPULAN}

Tingkat stres pada remaja laki-laki kelas XII di SMA Saraswati 1 Denpasar di dapatkan skor yang paling tinggi berada pada tingkat stres sedang sebanyak 27 responden $(41,5 \%)$, dan perilaku merokok pada remaja laki-laki kelas XII di dapatkan skor yang paling tinggi yaitu perilaku merokok kuat sebanyak 39 responden (60\%). Hubungan signifikan antara tingkat stres dengan perilaku merokok pada remaja laki-laki di SMA Saraswati 1 Denpasar dengan hasil $\mathrm{p}($ value $)=0,000$ yang berarti terdapat hubungan tingkat stres dengan perilaku merokok pada remaja laki-laki di SMA Saraswati 1 Denpasar. Hasil koefisien korelasi menunjukkan ${ }^{r}$-hitung $=0,532$ yang berarti korelasi termasuk dalam tingkat hubungan yang sedang, arah korelasi positif yaitu tinggi tingkat stres pada remaja, maka perilaku merokok pada remaja akan semakin kuat.

Diharapkan program PKPR di puskesmas lebih di tingkatkan agar remaja lebih mengerti akan dampak bahaya merokok serta peran perawat agar lebih aktif mengadakan penyuluhan ataupun diskusi kelompok dengan mengangkat trend dan isu-isu terkait kenakalan remaja, untuk peneliti lain agar mengembangkan skripsi ini lebih lanjut, dengan meneliti tentang faktor-faktor lain yang dapat menyebabkan perilaku merokok.

\section{DAFTAR PUSTAKA}

Windira, R. S. (2016) Hubungan Persepsi Visual Gambar Patologi Bahaya Merokok Pada Bungkus Rokok Dengan Perilaku Merokok Pada Remaja di SMKN 2 Jember. In Digital Repository Universitas Jember. https://doi.org/10.1242/jcs.150862

Whittaker, C. Tobacco Control. SA Pharmaceutical Journal, 77(4). https://doi.org/10.32398/cjhp.v3i3.64 9, 2010.

WHO, Global Youth Tobacco Survey (GYTS): Indonesia Report 2014. In Who-Searo.

https://doi.org/http://www.searo.who.i nt/tobacco/documents/ino_gyts_repor t_2014.pdf, 2015.

Indonesia, Hasil Utama Riset Kesehata Dasar (RISKESDAS), 2018.

Denpasar, Profil Kesehatan Provinsi Bali. 2017

Aula, Lisa Ellizabet. Stop Rokok!. Garailmu. Jogjakarta, 2010

Liem, A. (2016) Pengaruh Nikotin Terhadap Aktivitas Dan Fungsi Otak Serta Hubungannya Dengan Gangguan Psikologis Pada Pecandu Rokok. Buletin Psikologi, 18(2), 3750.

https://doi.org/10.22146/bpsi.11536

Widiansyah, M. (2014) Faktor-Faktor Penyebab Perilaku Remaja Perokok Di Desa Sidorejo Kabupaten Penajam Paser Utara. Journal Sosiologi, 2(4), 1-12. Retrieved from https://ejournal.sos.fisipunmul.ac.id/site/wpcontent/uploads/2014/10/penting (1002-14-12-04-55).pdf

Nasution, I. K. Stres Pada Remaja. Universitas Sumatra Utara, 1-26, 
2007.

Komasari, D., \& Mada, U. G. (2014) Faktor

Faktor Penyebab Merokok Pada

Remaja. Psikologi, 37-47(1), 37-47

Helmi, A. F. Pengelolaan Stress Pra-Purna

Bakti. Psikologika: Jurnal Pemikiran

Dan Penelitian Psikologi, 5(9). https://doi.org/10.20885/psikologika. vol5.iss9.art4, 2000

Erikson, E. H. Childhood and Society. Pustaka Pelajar: Yogyakarta, 1993.

Rani, M. \& N. M. (2018) Hubungan Pola Asuh Orang Tua Dengan Perilaku. 2(2), 196-203.

Saputra, A. (2012) Hubungan Antara Harga Diri Dengan Perilaku Merokok Pada Siswa Laki- Laki SMP Di Kota Bukit Tingi. Jurnal Ilmu Keperawatan, 13, 1-14.

Leventhal, H., \& Cleary, P. D. (1980) The smoking problem: A review of the research and theory in behavioral risk modification. Psychological Bulletin, $88(2)$, 370-405. https://doi.org/10.1037/00332909.88.2.370

Pamukht,B.D \& Irdawati, S. K. (2016) Hubungan Antara Tingkat Stres Dengan Perilaku Merokok Mahasiswa Laki-Laki Fakultas Ilmu Kesehatan Universitas Muhammadiyah Surakarta (Doctoral dissertation, Universitas Muhammadiyah Surakarta). 